\title{
Influência da Acifidicação da Fase Móvel Na Qualidade da Detecção e Separação Simultânea de Aflatoxinas M1 e B1 por Cromatografia Líquida de Alta Eficiência
}

\author{
Denise Castagnaro (I), Tania Aparecida Becker-Algeri (II), Eliana \\ Badiale Furlong (II), Deisy Alessandra Drunkler (I) \\ (I) UTFPR - Universidade Tecnológica Federal do Paraná (Av. Brasil, 4232, Caixa Postal 271), \\ (II) FURG - Universidade Federal do Rio Grande (Campus Carreiros - Avenida Itália, km 08 -
}

Caixa Postal 474 )

\section{Resumo}

A qualidade da detecção de compostos por cromatografia líquida de alta eficiência depende de alguns fatores, sendo a composição da fase móvel um dos itens de maior importância para uma separação eficiente. Ademais, na avaliação de multitoxinas, é conveniente a detecção simultânea visando principalmente à economia de tempo e reagentes. Tendo em vista esses aspectos, foi conduzido estudo com intuito de avalizar e otimizar a influência da acidificação na detecção e separação simultânea das aflatoxinas $\mathrm{M}_{1}$ e $\mathrm{B}_{1}\left(\mathrm{AFM}_{1}\right.$ e $\left.\mathrm{AFB}_{1}\right)$. Para tanto, os padrões das aflatoxinas foram preparados a partir da diluição em benzeno:acetonitrila (98:2) seguido de evaporação do solvente em corrente de nitrogênio. Para obtenção das soluções de trabalho $(1,0 \mu \mathrm{g} / \mathrm{L})$, os padrões foram ressuspendidos nas diferentes proporções de fase móvel estudadas as quais foram compostas de acetonitrila:metanol:água e acetonitrila:metanol:ácido acético $1 \%$, conforme estabelecido por dois planejamentos experimentais de misturas Simplex-centroid ( $\left.2_{3-1}\right)$, compostos por 10 ensaios cada. Para detecção, foi utilizado cromatógrafo a líquido de ultra alta eficiência e detector de fluorescência. Para eluição das aflatoxinas foi utilizada coluna C18 Acclaim PA2, $5 \mu \mathrm{m}(4,6$ x 250 mm) e método isocrático de eluição com tempo de corrida de 20 minutos. Os parâmetros cromatográficos

\footnotetext{
Referência:

Denise Castagnaro, Tania Aparecida Becker-Algeri, Eliana Badiale Furlong, Deisy Alessandra Drunkler. Influência da Acifidicação da Fase Móvel Na Qualidade da Deteç̧ão e Separação Simultânea de Aflatoxinas M1 e B1 por Cromatografia Líquida de Alta Eficiência. In: Anais do 12을 Congresso Latinoamericano de Microbiologia e Higiene de Alimentos - MICROAL 2014 [= Blucher Food Science Proceedings, num.1, vol.1]. São Paulo: Editora Blucher, 2014.

DOI $10.5151 /$ foodsci-microal-256
} 
avaliados foram: tempo e fator de retenção (k'), fator de separação ( $\alpha)$ e resolução da coluna (Rs). A partir da análise dos cromatogramas, observouse que os tempos de retenção dos analitos reduziram em relação à fase móvel não acidificada, sendo de 15 min para $\mathrm{AFB}_{1}$ e 8 min para $\mathrm{AFM}_{1}$. Nessas condições, os $\mathrm{k}$ foram de 13,8 para $\mathrm{AFB}_{1}$ e 6,7 para $\mathrm{AFM}_{1}$, respectivamente, $\alpha$ de 2,0 (total separação das aflatoxinas) e a Rs de 23,2. A melhor separação observada quando empregada fase móvel acidificada pode ser justificada pela maior ionização do analito que se torna menos hidrofóbico na fase móvel acidificada, reduzindo sua retenção na fase estacionária. Por fim, a acidificação da fase móvel permitiu que mais ensaios (7) detectassem e separassem as aflatoxinas em corrida de $20 \mathrm{~min}$, em contrapartida, quando utilizada fase móvel não acidificada, somente 4 ensaios apresentaram separação total das aflatoxinas. Diante dos resultados, verificou-se que a acidificação da fase móvel atua favoravelmente na detecção e separação simultânea das aflatoxinas avaliadas.

Palavras-Chave: Cromatografia, Micotoxinas, Planejamento de misturas Agência de Fomento: CNPq - Processo 475035/ 2013-5 